\title{
Investigation of Effective Immobilization Method for Ethanol Producing E. coli Strain
}

\author{
Taner Sar, Meltem Yesilcimen Akbas* \\ Department of Molecular Biology and Genetics, Gebze Technical University, Gebze-Kocaeli, Turkey \\ *akbasm@gtu.edu.tr
}

Received: 18 February 2019

Accepted: 16 May 2019

DOI: $10.18466 /$ cbayarfbe. 528451

\begin{abstract}
There is a growing interest to find alternative cheap carbon sources for bioethanol production. Whey powder is a by-product of cheese industry with high lactose content. Immobilization of bacteria is an effective method for enhancing production of their metabolites including bioethanol. In this work, a new and effective immobilization method for bioethanol production from whey powder as a cheap/renewable carbon source was investigated. For this, different immobilization methods were evaluated to avoid disruption of bead structures during ethanol fermentation. The best results were obtained when sodium alginate was sterilized under the UV lamp instead of heating for immobilization, and the fermentation media was supplemented with $\mathrm{CaCl}_{2}$ as a stability factor. In addition, the beads were successfully reused in at least three $48 \mathrm{~h}$ batch fermentations for ethanol production.
\end{abstract}

Keywords: E.coli, ethanol, immobilization, repeated batch fermentation, whey powder, lactose.

\section{Introduction}

Cheese whey is a dairy industry waste and contains lactose $(5-6 \%)$, protein $(1 \%)$, fat $(0.06 \%)$, several minerals and vitamins [1]. Cheese whey is a useful, inexpensive and alternative carbon source for microbial fermentation. Some countries such as New Zealand, the United States, and Denmark use cheese whey for producing ethanol [1, 2]. Whey powder is also concentrated form of cheese whey and contains more lactose. For ethanol production, Saccharomyces and Kluyveromyces are used as fermentative organisms. However, $S$. cerevisiae cannot utilize lactose and pentose sugars like xylose [3]. Kluyveromyces sp. ferments lactose to ethanol but it is not effective at moderate sugar concentrations compared with $S$. cerevisiae [4]. Escherichia coli can ferment various sugars such as lactose, glucose, fructose and xylose [5]. In previous studies, E.coli FBR5 strain was an alternative ethanol producer using different carbon sources including pure sugars, corn stover, potato processing waste water, corn and potato processing waste, sugar beet molasses and whey/ whey powder [6-11]. In addition, some strategies such as cell immobilization, VHb technology, coculturing and evolutionary adaptation have been conducted for enhancing bioethanol production (reviewed by Akbas and Stark [12]). Especially immobilization technology provides improvement of ethanol production through preventing contamination [13], reducing fermentation times [14] and allowing to reuse the organisms in repeated batch fermentations [11]. The common method for immobilization is cell entrapment in natural or synthetic polymers. For bacterial immobilization, sodium alginate has been evaluated as a natural and safe biopolymer by several researchers [10, $11,14]$. Therefore, in this work, an effective Ca-alginate immobilization method was investigated for bioethanol production.

\section{Materials and Methods \\ 2.1. Bacterial Strain}

In this work, E.coli FBR5 strain [5] was used for ethanol production.

\subsection{Immobilization}

For immobilization, E.coli FBR5 strain was incubated in LB media (peptone $10 \mathrm{~g} / \mathrm{L}$ and yeast extract $5 \mathrm{~g} / \mathrm{L} ; \mathrm{pH} 7.0$ ) at $180 \mathrm{rpm}$ for 24 hours at $37^{\circ} \mathrm{C}$. After incubation, the cell culture OD $600 \mathrm{~nm}$ was adjusted to 0.5 , and then $40 \mathrm{~mL}$ of cell culture was centrifuged at $4000 \mathrm{rpm}$ for 15 min at $4{ }^{\circ} \mathrm{C}$. The supernatant was removed and the cell pellet was used for immobilization. 5 different immobilization methods (A-E) were used for determining the best immobilization applications for ethanol production. The beads were approximately 3.0 $\mathrm{mm}$ in diameter.

After the immobilization, the beads were added into LB media and incubated at $180 \mathrm{rpm}$ for 24 hours at $37^{\circ} \mathrm{C}$ for ethanol production.

\section{Method A}

Sodium alginate (Sigma Aldrich, Germany) was mixed with distilled water to give $6 \%(\mathrm{w} / \mathrm{v})$ alginate solution. 
Alginate solution was heated at $121{ }^{\circ} \mathrm{C}$ for $15 \mathrm{~min}$ for sterilization.

The bacterial cell pellet was mixed with $20 \mathrm{~mL} \mathrm{NaCl}$ $(0.9 \%, \mathrm{w} / \mathrm{v})$ and $20 \mathrm{~mL}$ alginate $(6 \%, \mathrm{w} / \mathrm{v})$ solutions, respectively. The obtained cell-alginate mixture solution was dropped into $2 \%$ (w/v) $\mathrm{CaCl}_{2}$ solution and stirred for $30 \mathrm{~min}$. After the bead formation process, the beads were collected and washed with sterile distilled water. The beads were transferred into the 5 different storage solutions (Table 1) and stored at $+4{ }^{\circ} \mathrm{C}$ for 7 days.

\section{Method B}

Alginate was sterilized under the UV lamp in a Biosafety cabinet level II for $30 \mathrm{~min}$ and then mixed with sterile distilled water at a final concentration of $6 \%(\mathrm{w} / \mathrm{v})$. Alginate solution was stirred until homogeneous using by a magnetic stirrer. E.coli FBR5 strain was immobilized as described in method A procedure and then transferred into 5 different storage solutions (Table 1 ) at $+4{ }^{\circ} \mathrm{C}$.

\section{Method C}

Bead preparation was performed as in Method B procedure. The obtained beads were covered with $0.2 \%$ chitosan $(\mathrm{w} / \mathrm{v})$ in a beaker for $60 \mathrm{~min}$. Then, the beads were collected and stored in 5 different storage solutions (Table 1).

\section{Method D}

Beads were obtained according to method B and dried on a filter paper at room temperature for $60 \mathrm{~min}$. The dried beads were stored in storage solutions (Table 1).

\section{Method E}

Alginate was sterilized using UV lamp for $30 \mathrm{~min}$ as performed in method $\mathrm{B}$ and then mixed with sterile distilled water at the final concentration of $3 \%(\mathrm{w} / \mathrm{v})$. The alginate solution was mixed with Tween 20 to give $0.1 \%$ (v/v) final concentration of alginate. In addition, $0.65 \%$ CMC (carboxymethylcellulose; w/v) was added into the $2 \% \mathrm{CaCl}_{2}(\mathrm{w} / \mathrm{v})$ solution.

For immobilization, the cell pellet was mixed with $40 \mathrm{~mL}$ alginate-Tween20 solution and then dropped into the $\mathrm{CaCl}_{2}-\mathrm{CMC}$ solution, and stirred for $30 \mathrm{~min}$. The beads were transferred into the 5 different storage solutions (Table 1) and stored at $+4{ }^{\circ} \mathrm{C}$.

Table 1. Different storage solutions (SS1-SS5) for immobilized beads.

\begin{tabular}{|c|c|}
\hline $\begin{array}{l}\text { Storage } \\
\text { Solutions } \\
\text { (SS) }\end{array}$ & Ingredient \\
\hline SS1 & $2 \% \mathrm{CaCl}_{2}(\mathrm{w} / \mathrm{v})$ \\
\hline SS2 & $0.2 \%$ Glucose $(\mathrm{w} / \mathrm{v})$, and \\
\hline SS3 & $10 \%$ Glycerol (v/v) \\
\hline SS4 & $0.9 \% \mathrm{NaCl}(\mathrm{w} / \mathrm{v})$ \\
\hline SS5 & PBS (Phosphate Buffer, pH at 7.0) \\
\hline
\end{tabular}

\subsection{Preparation of Fermentation Media and Fermantation}

In this study, cheese whey powder was obtained by Bahçıvan Gıda (Kırklareli, Turkey) and used as a carbon source (78-80\% lactose, w/v). For preparing the cheese whey powder solution, whey powder $(128 \mathrm{~g})$ was diluted with distilled water $(400 \mathrm{~mL})$ and heated at $121^{\circ} \mathrm{C}$ for 15 min for sterilization. The obtained solution was centrifuged at $10000 \mathrm{rpm}$ for $10 \mathrm{~min}$ and then $\mathrm{pH}$ adjusted as 7.0 using with $10 \mathrm{~N} \mathrm{NaOH}$ or $1 \mathrm{~N} \mathrm{HCl} \mathrm{[10-11].}$

In this work, 6 different fermentation media were used (Table 2). The lactose contents of the media were supplied from whey or lactose solution. Initial lactose concentration of fermentation media was set at $5 \%(\mathrm{w} / \mathrm{v})$. These media were supplemented with $\mathrm{CaCl}_{2}(5 \mathrm{~g} / \mathrm{L})$, or $\mathrm{CaCl}_{2}(5 \mathrm{~g} / \mathrm{L})$ and yeast extract, or $\mathrm{CaCl}_{2}(5 \mathrm{~g} / \mathrm{L})$, yeast extract and peptone (Table 2).

All of the fermentation media $(40 \mathrm{~mL})$ were transferred into $50 \mathrm{~mL}$ Erlenmeyer Flasks. The free cells (initial cell concentration was set as $\mathrm{OD}_{600 \mathrm{~nm}}$ 0.04) or immobilized cells ( 10 beads) were incubated at $37^{\circ} \mathrm{C}, 100$ or $200 \mathrm{rpm}$ for 48 hours.

\section{Results and Discussion \\ 3.1. Immobilization}

When immobilized cells were stored with different types of storage solutions, the structures of beads were maintained in the SS1, SS2, SS3, and SS4 for 7 days at $4^{\circ} \mathrm{C}$. However, the beads were disrupted in the SS5 (PBS Buffer) solution after they were stored.

After storage, the beads prepared according to method A and stored for 7 days were disrupted in the fermentation media after 24 hours at $37^{\circ} \mathrm{C}, 100$ or $200 \mathrm{rpm}$. This could be due to the heating step during sodium alginate sterilization. The beads obtained by method B and stored for 7 days were maintained in the fermentation media when they were incubated at $37^{\circ} \mathrm{C}$ with shaking at 100 or $200 \mathrm{rpm}$ for 48 hours. Thus, the beads were collected and washed with sterile distilled water and then transferred into the fresh media. During the second fermentation the beads were disrupted in 48 hours. Therefore, the beads were reprepared as described in method $\mathrm{B}$ and stored for 7 days at $4{ }^{\circ} \mathrm{C}$. These beads were incubated in $\mathrm{LB}$ media enriched with $\mathrm{CaCl}_{2}(5 \mathrm{~g} / \mathrm{L}$, w/v). In $\mathrm{CaCl}_{2}$ containing $\mathrm{LB}$ medium no morphological change on beads was observed during the second and then the third repeated batches during 48 hour fermentation period. The beads attained from method $\mathrm{C}$ were disrupted in $\mathrm{LB}$ medium enriched $\mathrm{CaCl}_{2}$ after 24 hour incubation. The beads prepared by using method D retained their structures in the $\mathrm{LB}$ media enriched with $\mathrm{CaCl}_{2}$ in 48 hours, at $37^{\circ} \mathrm{C}$ with shaking at 100 or 200 rpm. The beads obtained by using method $\mathrm{E}$ were maintained in the $\mathrm{LB}$ media enriched with $\mathrm{CaCl}_{2}$ after the same incubation conditions. 
Table 2. The contents of different fermentation media.

\begin{tabular}{lll}
\hline Substrate & Media & Contents of Media \\
\hline Whey powder & WP1 & $5 \mathrm{~g} / \mathrm{L} \mathrm{CaCl}_{2}$ \\
& WP2 & $5 \mathrm{~g} / \mathrm{L} \mathrm{CaCl}_{2}+5 \mathrm{~g} / \mathrm{L}$ yeast \\
Lactose & WP3 & $5 \mathrm{~g} / \mathrm{L} \mathrm{CaCl}_{2}+5 \mathrm{~g} / \mathrm{L}$ yeast $+10 \mathrm{~g} / \mathrm{L}$ peptone \\
& ML1 & $5 \mathrm{~g} / \mathrm{L} \mathrm{CaCl}_{2}$ \\
& ML2 & $5 \mathrm{~g} / \mathrm{L} \mathrm{CaCl}_{2}+5 \mathrm{~g} / \mathrm{L}$ yeast \\
& ML3 & $5 \mathrm{~g} / \mathrm{L} \mathrm{CaCl}_{2}+5 \mathrm{~g} / \mathrm{L}$ yeast $+10 \mathrm{~g} / \mathrm{L}$ peptone \\
\hline
\end{tabular}

It was determined that $\mathrm{CaCl}_{2}$ as a supportive supplement necessary for the improvement of bead structure.

\subsection{Repeated Batch Fermentations}

The beads prepared by method B and stored in SS2 were selected since they were physically the best with no swelling or shrinking behavior after 7 days storage compared to other storage solutions. These beads were successfully reused in repeated batch fermentations with the lactose-containing media (Table 3) enriched with $\mathrm{CaCl}_{2}$. The calcium ions could improve the calciumalginate structure during the fermentations and prevented beads from swelling [15]. Therefore, all fermentation media were supplemented with $\mathrm{CaCl}_{2}$ [16].
In the repeated batch fermentations, the lowest cell growth profiles were observed in the low shaking conditions $(100 \mathrm{rpm})$. In addition, the $\mathrm{OD}_{600 \mathrm{~nm}}$ values were much higher at $200 \mathrm{rpm}$ shaking with whey powder, yeast and peptone supplementations (Table 3). However, the beads were reused at least 3 successive fermentation runs both with lactose (ML) and whey powder (WP) media.

According to $\mathrm{OD}_{600 \mathrm{~nm}}$ values of free cells, the cell growth in both WP1 and ML1 were too low after 48 hours at 37 ${ }^{\circ} \mathrm{C}$ with shaking at 100 or $200 \mathrm{rpm}$ (Table 3). Therefore, the fermentation media were supplemented with yeast extract or combination of yeast extract and peptone were found to be more effective for cellular growth.

Table 3. The $\mathrm{OD}_{600 \mathrm{~nm}}$ values of free cells and immobilized cells in different media after three successive batches fermentations.

\begin{tabular}{llcccc}
\hline & \multirow{2}{*}{ Media } & \multirow{2}{*}{ Free cells } & \multicolumn{3}{c}{ Immobilized Cells } \\
\cline { 4 - 6 } & & 1. Batch & 2. Batch & 3. Batch \\
\hline $\mathbf{1 0 0} \mathbf{~ r p m}$ & WP1 & 0.73 & 0.95 & 0.79 & 0.59 \\
& WP2 & 2.61 & 2.14 & 1.80 & 2.02 \\
& WP3 & 2.36 & 2.27 & 3.60 & 2.23 \\
& ML1 & 0.14 & 0.06 & 0.06 & 0.08 \\
& ML2 & 4.27 & 1.40 & 1.45 & 1.71 \\
& ML3 & 4.82 & 2.38 & 2.36 & 2.50 \\
& WP1 & 0.73 & 2.14 & 1.90 & 2.10 \\
& WP2 & 1.84 & 6.23 & 4.66 & 6.23 \\
& WP3 & 1.91 & 7.23 & 5.38 & 7.39 \\
& ML1 & 0.19 & 0.12 & 0.06 & 0.09 \\
& ML2 & 2.80 & 1.62 & 2.51 & 2.72 \\
& ML3 & 3.67 & 3.25 & 3.02 & 2.94 \\
\hline
\end{tabular}

\section{Discussion}

The food industry wastes have been intensively investigated for ethanol production [6-11, 17]. Cheese whey and whey powder were effectively used for metabolite production [8, 18]. New and efficient strategies needed to be performed for improving bioethanol production. Immobilization of cells has many advantages like using cells in repeated batch fermentations for several times, improving the yield and reducing the fermentation times. During efficient fermentation, immobilized bead structures should be maintained and successfully used several times. Some of the ingredients like $\mathrm{CaCO}_{3}[19]$ or $\mathrm{CaCl}_{2}$ [16] were added into the fermentation media for stabilizing the structure of calcium-alginate beads. It was also reported that calcium supplementations $\left(\mathrm{CaCO}_{3}\right.$ and $\left.\mathrm{CaCl}_{2}\right)$ improved the ethanol yields [20]. 
It can be concluded that the structure of beads was maintained by using UV for sterilization of sodium alginate instead of heating treatment. In addition, $\mathrm{CaCl}_{2}$ supplementation into the fermentation media had beneficial effect on bead stability. The beads were also reused at least 3 repeated batch fermentations.

In this work, an effective immobilization method (method B) was determined for repeated batch fermentations. It was also shown that the immobilized beads could be stored at different types of storage solutions except PBS buffer. These results could be useful for immobilization of ethanol producing organisms for large scale fermentations in industrial use.

\section{Acknowledgement}

We would like to thank the Gebze Technical University (2016-A-13 and 2017-A102-19), Turkey, and Bahçıvan Gida (Kirklareli, Turkey) for providing whey powder.

\section{Author's Contributions}

Taner Sar: Performed the experiment, analyzed data, and wrote the manuscript.

Meltem Yesilcimen Akbas: Analyzed data, supervised the experiment's progress, and wrote the manuscript.

\section{Ethics}

There are no ethical issues after the publication of this manuscript.

\section{References}

1. Siso, MIG. 1996. The biotechnological utilization of cheese whey: A review. Bioresource Technology; 57: 1-11.

2. Das, B, Sarkar, S, Maiti, S, Bhattacharjee, S. 2016. Studies on production of ethanol from cheese whey using Kluyveromyces marxianus. Mater Today: Proceedings; 3: 3253-3257.

3. Ha, SJ, Galazka, JM, Kim, SR, Choi, JH, Yang, X, Seo JH, Glass NJ, Cate JHD, Jin YS. 2011. Engineered Saccharomyces cerevisiae capable of simultaneous cellobiose and xylose fermentation. Proceedings of the National Academy of Sciences; 108(2): 504509.

4. Zafar, S, Owais, M, Saleemuddin, M, Husain, S. 2005. Batch kinetics and modelling of ethanolic fermentation of whey. International Journal of Food Science \& Technology; 40(6): 597604.

5. Dien, BS, Nichols, NN, O'bryan, PJ, Bothast, RJ. 2000 Development of new ethanologenic Escherichia coli strains for fermentation of lignocellulosic biomass. Applied Microbiology and Biotechnology; 84-86: 181-196.

6. Sanny, T, Arnaldos, M, Kunkel, SA, Pagilla, KR, Stark, BC. 2010. Engineering of ethanolic E. coli with the Vitreoscilla hemoglobin gene enhances ethanol production from both glucose and xylose. Applied Microbiology and Biotechnology; 88: 1103-1112.
7. Abanoz, K., Stark, BC., Akbas, MY. 2012. Enhancement of ethanol production from potato-processing wastewater by engineering Escherichia coli using Vitreoscilla haemoglobin. Letters in applied microbiology; 55(6): 436-443.

8. Akbas, MY, Sar T, Ozcelik B. 2014. Improved ethanol production from cheese whey, whey powder, and sugar beet molasses by "Vitreoscilla hemoglobin expressing" Escherichia coli. Bioscience, Biotechnology, and Biochemistry; 78(4): 687-694.

9. Sumer, F, Stark, BC, Akbas, MY. 2015. Efficient ethanol production from potato and corn processing industry waste using E. coli engineered to express Vitreoscilla haemoglobin. Environmental Technology; 36(18): 2319-2327.

10. Sar, T, Stark, BC, Akbas, MY. 2017a. Effective ethanol production from whey powder through immobilized E. coli expressing Vitreoscilla hemoglobin. Bioengineered; 8(2); 171-181.

11. Sar, T, Seker, G, Erman, AG, Stark, BC, Akbas, MY. $2017 \mathrm{~b}$. Repeated batch fermentation of immobilized $E$. coli expressing Vitreoscilla hemoglobin for long-term use. Bioengineered; 8(5): 651-660.

12. Akbas, MY, Stark, BC. 2016. Recent trends in bioethanol production from food processing byproducts. Journal of Industrial Microbiology \& Biotechnology; 43(11): 1593-1609.

13. Razmovski, R, Vučurović, V. 2012. Bioethanol production from sugar beet molasses and thick juice using Saccharomyces cerevisiae immobilized on maize stem ground tissue. Fuel; 92: 18

14. Karagoz, P, Ozkan, M. 2014. Ethanol production from wheat straw by Saccharomyces cerevisiae and Scheffersomyces stipitis coculture in batch and continuous system. Bioresource Technology; 158: 286-93.

15. Cheong, SH, Park, HK, Kim, BS, Chang, HN. 1993. Microencapsulation of yeast cells in the calcium alginate membrane. Biotechnology Techniques; 7: 879-84.

16. Chang, HN, Seong, GH, Yoo, IK, Park, JK, Seo, JH. 1996. Microencapsulation of recombinant Saccharomyces cerevisiae cells with invertase activity in liquid core alginate capsules. Biotechnology and Bioengineering; 51: 157-162.

17. Şar, T, Akbaş, MY. 2016. Biyoetanol üretimi için gıda işleme atıklarının asit hidrolizi. Academic Food Journal/Akademik GIDA; 14(1): $15-20$.

18. Ozmihci, S, Kargi, F. 2007. Ethanol fermentation of cheese whey powder solution by repeated fed-batch operation. Enzyme and Microbial Technology, 41:169-74.

19. Singh, PK, Deol, PK, Kaur, IP. 2012. Entrapment of Lactobacillus acidophilus into alginate beads for the effective treatment of cold restraint stress induced gastric ulcer. Food \& Function; 3(1): 8390.

20. Azam, MM, Ezeji, TC, Qureshi, N. 2014. Novel technologies for enhanced production of ethanol: Impact of high productivity on process economics. European Chemical Bulletin, 3(9): 904-910. 